\title{
Mercury Concentrations of Bluegill (Lepomis macrochirus) Vary by Sex
}

\section{Charles P. Madenjian ${ }^{1, *}$, James T. Francis ${ }^{2}$, Jeffrey J. Braunscheidel ${ }^{2}$, Joseph R. Bohr ${ }^{3}$, Matthew J. Geiger ${ }^{4}$ and G. Mark Knottnerus ${ }^{4}$}

1 U.S. Geological Survey, Great Lakes Science Center, 1451 Green Road, Ann Arbor, MI 48105, USA

2 Michigan Department of Natural Resources, Waterford Fisheries Station, 7806 Gale Road, Waterford, MI 48327, USA; E-Mails: francisj@michigan.gov (J.T.F.); braunscheidelj@michigan.gov (J.J.B.)

3 Michigan Department of Environmental Quality, 525 West Allegan Street, P. O. Box 30473, Lansing, MI 48909, USA; E-Mail: bohrj@michigan.gov

4 Michigan Department of Health and Human Services, Bureau of Laboratories, 3350 North Martin Luther King Jr. Boulevard, Lansing, MI 48906, USA; E-Mails: geigerm@michigan.gov (M.J.G.); knottnerusm@michigan.gov (G.M.K.)

* Author to whom correspondence should be addressed; E-Mail: cmadenjian@usgs.gov; Tel.: +1-734-214-7259; Fax: +1-734-994-8780.

Academic Editors: Roberta Bettinetti and Yu-Pin Lin

Received: 31 August 2015 / Accepted: 2 November 2015 / Published: 11 November 2015

\begin{abstract}
Patterns in relative differences in contaminant concentrations between the sexes across many species of fish may reveal clues for important behavioral and physiological differences between the sexes, and may also be useful in developing fish consumption advisories and efficient designs for programs meant to monitor contaminant levels in fish. We determined skin-off fillet and whole-fish total mercury $(\mathrm{Hg})$ concentrations of 28 adult female and 26 adult male bluegills (Lepomis macrochirus) from Squaw Lake, Oakland County, Michigan (MI), USA. Bioenergetics modeling was used to quantify the effect of growth dilution on the difference in $\mathrm{Hg}$ concentrations between the sexes. On average, skin-off fillet and whole-fish $\mathrm{Hg}$ concentrations were $25.4 \%$ higher and $26.6 \%$ higher, respectively, in females compared with males. Thus, the relative difference in $\mathrm{Hg}$ concentrations between the sexes for skin-off fillets was nearly identical to that for whole fish. However, mean skin-off fillet $\mathrm{Hg}$ concentration $(363 \mathrm{ng} / \mathrm{g})$ was 2.3 times greater than
\end{abstract}


mean whole-fish $\mathrm{Hg}$ concentration (155 ng/g). Males grew substantially faster than females, and bioenergetics modeling results indicated that the growth dilution effect could account for females having $14.4 \%$ higher $\mathrm{Hg}$ concentrations than males. Our findings should be useful in revising fish consumption advisories.

Keywords: bioenergetics modeling; consumption advisories; excretion; gross growth efficiency; Hg elimination rates; sex differences; tracers of food consumption

\section{Introduction}

The bluegill (Lepomis macrochirus) is the most angled and harvested fish in many areas of North America [1-4]. Moreover, bluegills have been exported worldwide to propagate sport fisheries and aquaculture, as well as to provide a forage base for larger predatory fishes [3,5,6]. Improving management of sport fisheries for bluegills has been the focus of numerous scientific investigations [1,2,7-11]. In addition, the bluegill has been the subject of many fish behavior studies, because cuckoldry and other variations in life history characteristics have been documented [12-16]. For example, some males mimic females in coloration to "sneak" access to fertilization of eggs in nests guarded by parental males that build the nests and care for the eggs; these parental males typically represent the bulk of the adult male population.

Mercury has become a globally dispersed pollutant via atmospheric emissions, notably from the burning of coal, and the subsequent transport through the atmosphere [17]. Through a complex series of linked environmental processes that are not completely understood, mercury contamination can lead to exposure levels in aquatic and terrestrial food webs of toxicological concern in even the most remote locations. Mercury contamination has received much attention from environmental health managers, who have ranked mercury as one of the 10 chemicals of major public health concern worldwide [18]. Mercury biomagnifies in food webs, and top predator species, including humans, may therefore exhibit relatively high mercury concentrations [17]. A sufficiently high exposure to mercury can lead to impairment of the proper functioning of their nervous systems, deformities in neonates, and liver damage [19-21]. The brain of fetal humans is more susceptible to mercury-induced damage than the brain of adult humans [22]. Mercury can inhibit the division and migration of neuronal cells in the brain of a human fetus, thereby disrupting the cytoarchitecture of the developing brain. Mercury exposure has also been linked to subclinical autoimmunity among reproductive-age women [23]. Mercury contamination in fish is of special concern, because consumption of contaminated fish is the predominant source of mercury exposure to humans and fish-eating wildlife [19,24]. Determinations of mercury concentrations in fish are essential to developing fish consumption advisories and to assessing risk to humans and wildlife consuming contaminated fish [19,25-29].

Two apparent patterns have recently emerged with regard to whole-fish contaminant concentrations in males versus whole-fish contaminant concentrations in females of various fish species [30,31]. First, polychlorinated biphenyl (PCB) concentrations in males have been shown to exceed PCB concentrations of females by $15 \%-45 \%$. This difference has been primarily attributed to a higher rate of energy expenditure, stemming from greater activity and a higher resting metabolic rate (or standard 
metabolic rate, SMR), in males. The higher rate of energy expenditure leads to a higher rate of food consumption, which, in turn, leads to a faster rate of PCB accumulation. Second, with the exception of sea lamprey (Petromyzon marinus), the ratio of total mercury $(\mathrm{Hg})$ concentration in males to $\mathrm{Hg}$ concentration in females is substantially lower than the ratio of PCB concentration in males to PCB concentration in females. This phenomenon has been attributed to males eliminating $\mathrm{Hg}$ from their bodies at a faster rate than females, whereas long-term elimination of PCBs is negligible for both sexes of fish. Hg-elimination rate appears to be enhanced by androgens such as testosterone and 11-ketotestosterone [31,32]. The sea lamprey, a very primitive fish, lacks these two androgens, and this would explain the ratio of $\mathrm{Hg}$ concentration in males to $\mathrm{Hg}$ concentration in females equaling the ratio of PCB concentration in males to PCB concentration in females [31].

Although Nicoletto and Hendricks [33] reported significantly greater $\mathrm{Hg}$ concentrations in females compared with males for four species of sunfishes, including bluegill, these differences were based on sampling just a small (about $0.5 \mathrm{~g}$ ) plug from the dorsal region of the white muscle tissue from each fish. Females were found to be $40 \%-50 \%$ higher in $\mathrm{Hg}$ concentration than males. However, to the best of our knowledge, differences in whole-fish $\mathrm{Hg}$ concentrations between the sexes of bluegill have yet to be investigated. When comparing contaminant concentration in males with that in females, caution must be exercised in using concentrations in muscle tissue or liver tissue as a surrogate for whole-fish concentrations [34]. The relative difference in muscle or liver tissue contaminant concentrations between the sexes may accurately reflect the relative difference in whole-fish contaminant concentrations between the sexes in some cases but not in others. Several other researchers have determined $\mathrm{Hg}$ concentrations in bluegills, but differences in concentrations between the sexes were not addressed [35-38]. Becker and Bigham [35] reported that the skin-on fillet $\mathrm{Hg}$ concentrations were 1.6 times greater than whole-fish Hg concentrations in bluegill.

The overall goal of our study was to characterize $\mathrm{Hg}$ accumulation in bluegills from Squaw Lake, a small lake in southeastern Michigan (USA). The specific objectives were to: (1) estimate the mean skin-off fillet and whole-fish $\mathrm{Hg}$ concentrations for bluegills from Squaw Lake, (2) quantify the difference between the sexes of bluegills for both skin-off fillet $\mathrm{Hg}$ concentrations and whole-fish $\mathrm{Hg}$ concentrations, (3) use bioenergetics modeling to assess the effect of growth dilution on the observed difference in $\mathrm{Hg}$ concentrations between the sexes, (4) identify the factors most likely responsible for the observed difference in $\mathrm{Hg}$ concentrations between the sexes, and (5) discuss the implications of our results with regard to revising fish consumption advisories for southeastern Michigan.

\section{Materials and Methods}

\subsection{Field Methods}

Squaw Lake is a shallow lake located in southeastern Michigan (Figure 1). Three fyke nets, each with 38-mm mesh (stretched-measure) in the pot and a $30.5-\mathrm{m}$ lead, were set at randomly selected locations in Squaw Lake on 28 May 2013, according to procedures contained in the survey methods manual [39]. The lead extended from shore to the opening of the fyke net located in water between 0.6 and $1.2 \mathrm{~m}$ deep. Fyke nets were lifted on 29 May 2013 and 30 May 2013, and the catches were randomly subsampled to select 27 apparently female bluegills and 27 apparently male bluegills for $\mathrm{Hg}$ 
determinations. Bluegills were sexed in the field based on their coloration pattern and abdomen width [40], and then later the assignment of sex in the field was verified in the laboratory via visual examination of the gonads. All fish were in ripe or nearly ripe condition. All fish were measured to the nearest 2.5 millimeters and weighed to the nearest gram, and aging structures (scales and dorsal spines) were taken from each fish. Scales and spines were processed according to standard methods in the survey manual [41]. Scales were pressed onto plastic slides to create growth ring impressions, and spines were sectioned for direct reading of growth rings. Ages were assigned based on enumeration of annuli; scales were used to age bluegills less than $153 \mathrm{~mm}$ total length (TL), and dorsal spines were used to age bluegills $\geq 153 \mathrm{~mm}$ in TL [41]. Bluegills were individually bagged in plastic bags, with each bag containing a cardboard tag with a unique identification number, frozen at $-20{ }^{\circ} \mathrm{C}$, and later transported to Bureau of Laboratories in Lansing, MI for further processing.

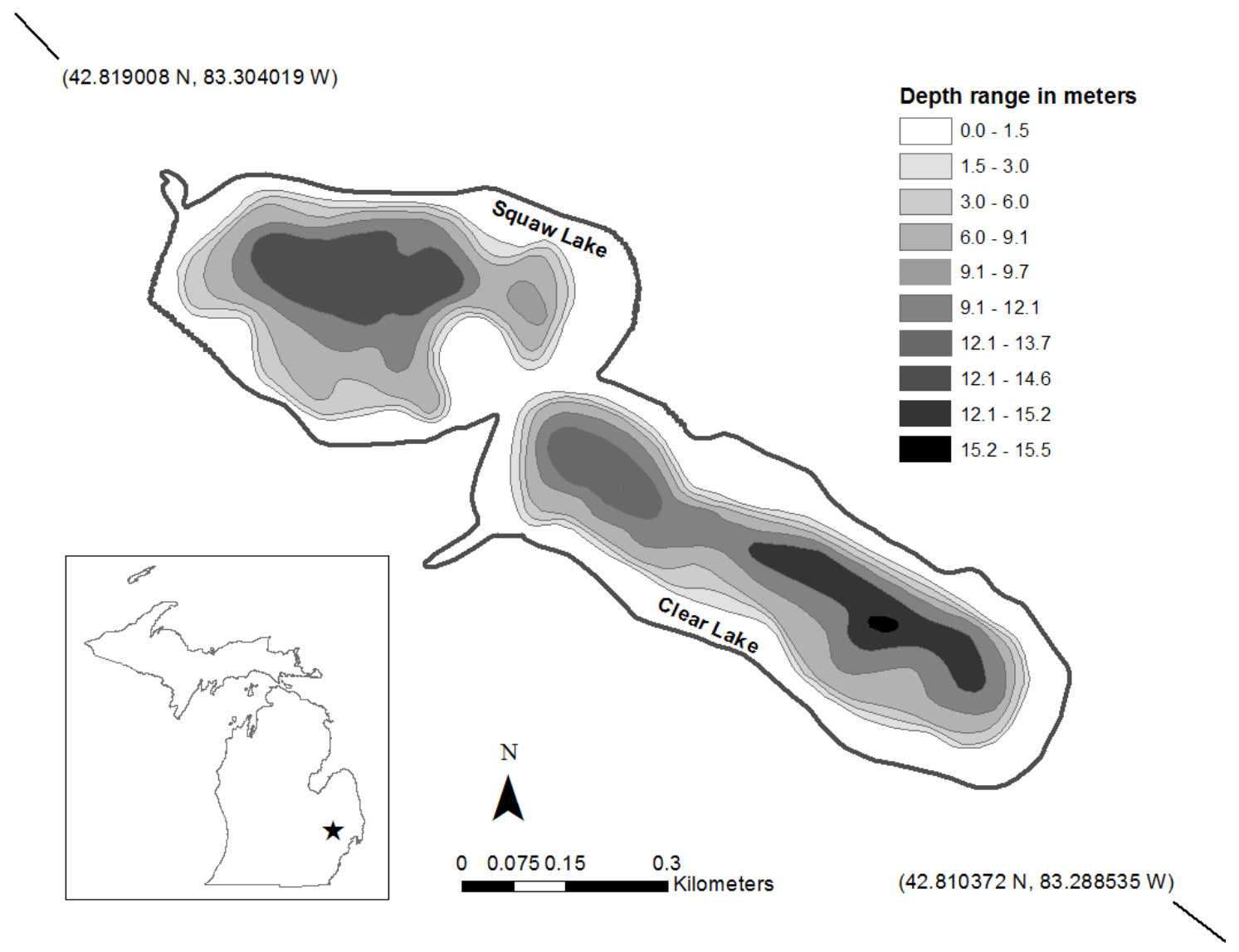

Figure 1. Map of Squaw Lake, Oakland County, MI, USA.

\subsection{Hg Determinations}

At the Bureau of Laboratories, bluegills were partially thawed, and skin-off fillets were prepared. Each bluegill was sexed in the laboratory via visual inspection of the gonads. For each bluegill, the skin-off fillet portion of the fish was homogenized in a commercial food processor with dry ice. A 0.1 -g sample of the skin-off fillet homogenate was placed in a clean vial for total mercury $(\mathrm{Hg})$ determination. All of the remaining skin-off fillet homogenate was added to the rest of the bluegill, and then homogenized in a commercial food processor with dry ice. A 0.1-g sample of this whole-fish homogenate was placed in a clean vial for $\mathrm{Hg}$ determination. 
Total mercury $(\mathrm{Hg})$ concentration was determined in both the skin-off fillet and whole-fish homogenates using U.S. Environmental Protection Agency Method 7473 [42]. Homogenized fish tissue samples were weighed to the nearest 0.1 milligrams in ceramic boats, and then introduced into the furnace of the Direct Mercury Analyzer (DMA) (Nippon MA-3000, Tokyo, Japan). In the furnace, the samples were dried and then thermally and chemically decomposed. Absorbance was measured twice at a wavelength of $253.65 \mathrm{~nm}$, using two different sensitivities. All $\mathrm{Hg}$ concentrations were reported on a wet-weight basis. Although the mercury found in the bluegills can be either methylmercury $(\mathrm{MeHg})$ or in the inorganic form, previous research has shown that nearly all (>95\%) of the mercury in bluegills from Lake Onondaga (New York, USA) is MeHg [35].

The DMA instrument was calibrated by an eight-point curve with a minimum correlation coefficient of 0.997 . Daily calibration check standards (5 ng and $50 \mathrm{ng}$ ) were analyzed with a minimum accuracy of $\pm 10 \%$. Quality control samples consisting of blanks, duplicates, and two certified reference materials (CRMs) from the National Research Council of Canada were analyzed with each set of homogenate samples to validate the accuracy and precision of the method. TORT-3 (lobster hepatopancreas) was the CRM used for accuracy in the long-path cell, while DORM-4 (fish protein reference material) was used for accuracy in the short-path cell. Duplicates were run with a frequency of one per 20 samples, and the mean relative percent difference between duplicates was $5.4 \%$. The method detection limit was calculated to be $0.4 \mathrm{ng} / \mathrm{g}$.

\subsection{Data Analyses for $\mathrm{Hg}$ Concentrations}

To test whether sex had a significant effect on $\mathrm{Hg}$ concentration, we applied analysis of covariance (ANCOVA), with Hg concentration as the dependent variable, sex as the main effect, and age as the covariate. One ANCOVA was performed for $\mathrm{Hg}$ concentration in the skin-off fillets and a second ANCOVA was performed for whole-fish $\mathrm{Hg}$ concentration. For both skin-off fillets and whole fish, we substituted the grand mean value for age into the fitted ANCOVA model to estimate the mean $\mathrm{Hg}$ concentration for both females and males. We then calculated the ratio of the estimate of mean $\mathrm{Hg}$ concentration of females to the estimate of mean $\mathrm{Hg}$ concentration of males. Equality of slopes of the regression line of $\mathrm{Hg}$ concentration as a function of age for males and that for females was a key assumption of the ANCOVA. Therefore, we performed the $F$ test for equality of slopes to ensure that this assumption was met. We set $\alpha=0.05$ for all of our statistical testing.

To determine whether skin-off fillet $\mathrm{Hg}$ concentration was significantly different from whole-fish $\mathrm{Hg}$ concentration, we applied a $t$ test for paired comparisons by pairing each skin-off fillet $\mathrm{Hg}$ concentration with its corresponding whole-fish $\mathrm{Hg}$ concentration, subtracting the whole-fish $\mathrm{Hg}$ concentration from the skin-off fillet $\mathrm{Hg}$ concentration, and then ascertaining whether the mean difference was significantly different from zero. Sexes were pooled for this statistical testing. We also calculated the ratio of mean $\mathrm{Hg}$ concentration in the skin-off fillets to mean whole-fish $\mathrm{Hg}$ concentration.

\subsection{Bioenergetics Modeling}

Bioenergetics modeling was used to assess the effect of growth dilution on the difference in $\mathrm{Hg}$ concentrations between the sexes of bluegill; please refer to Madenjian [34] for more details on this approach. In brief, gross growth efficiency (GGE) is defined as the amount of growth by a fish divided 
by the amount of food consumption needed to achieve that growth, and $\mathrm{Hg}$ concentration is inversely proportional to GGE. Thus, if the difference in $\mathrm{Hg}$ concentration was entirely due to a difference in GGEs between the sexes, then the ratio of $\mathrm{Hg}$ concentration in females to $\mathrm{Hg}$ concentration in males should equal the ratio of GGE for males to GGE for females. According to the Madenjian [34] approach, bioenergetics modeling is used to quantify the relative difference in GGEs between the sexes that is solely due to a difference in growth rates between the sexes, and this quantification represents the magnitude of the growth dilution effect. Thus, SMR and activity did not vary between the sexes in performing this bioenergetics modeling.

Growth trajectories were developed for both female and male bluegills, based on our weight and age data. Age was reported in years. Sample sizes were relatively low for ages 3, 4, 7, and 8, but were relatively high for ages 5 and 6 . Thus, we assigned the weights of age- 5 and age- 6 females and males values equal to the mean weights of age- 5 and age- 6 females and males, respectively, in our sample. We assumed that both female and male age-2 bluegills weighed $15 \mathrm{~g}$ in late May [41]. We further assumed that bluegill weight increased linearly between ages 2 and 5 for both sexes. Our data indicated that bluegill weight in Squaw Lake showed an annual increase of $22 \mathrm{~g}$ after age 5 for both sexes, and this information was used to complete growth trajectories over ages 2-8 for both sexes. Diet composition data were insufficient to estimate food consumption by age- 0 and age- 1 bluegills, and therefore we assigned cumulative GGE for age-2 bluegill the value of 0.1875 , which is an average GGE for age- 0 and age-1 fish from two previous studies on bloater (Coregonus hoyi) and walleye (Sander vitreus) [43,44]. The bluegills used in our study were caught on 29-30 May 2013, and therefore we designated 30 May as the starting day in our bioenergetics model simulations.

A modified version of the bluegill bioenergetics model, which was originally developed by Kitchell et al. [45] and coded into a computer program by Hewett and Johnson [46], was applied to the above-mentioned bluegill growth trajectories to estimate food consumption by an average female bluegill and an average male bluegill from Squaw Lake. Our modification was to change the value of the exponent for effect of weight on metabolism, RB, from -0.200 to -0.269 , as recommended by Breck [47]. The bluegill bioenergetics model represented an energy budget for the bluegill. Energy losses were calculated as functions of water temperature, bluegill size (weight), and food consumption, and the amount of food consumption needed to obtain the observed size (weight) at a given age was estimated via balancing of the energy budget. The bluegill's energy budget can be written as:

$$
C=G+R+E g+E x+S
$$

where $C$ = consumption, $G=$ growth, $R=$ respiration, $E g=$ egestion, $E x=$ excretion, and $S=$ spawning losses. Respiration was modeled as a function of bluegill weight and water temperature. Egestion of fecal matter and excretion of nitrogenous wastes were modeled as functions of food consumption, bluegill weight, and water temperature. Spawning was simulated by bluegills losing the appropriate amount of weight on the spawning day. Based on gonadosomatic index (GSI) determinations of bluegills nearing spawning time [48], mature females and mature males were assumed to lose $9.3 \%$ and $1.5 \%$, respectively, of their body weight on the spawning day. In most years, peak bluegill spawning in Squaw Lake occurs during the last week of May, but peak spawning may be delayed to the first week of June during years of relatively slow spring warming. Because 2013 was a year of relatively slow spring warming, we designated 1 June as the spawning day in our bioenergetics model 
simulations. Based on age determinations of the bluegills from our study, we assumed that females and males became mature at ages 4 and 3, respectively, in our bioenergetics model simulations.

Input data, including the water temperature regime experienced by the bluegills, diet composition, and energy densities of both prey and the bluegill, for the bioenergetics model simulations were taken from a variety of sources. Daily water temperature data for Greens Lake, a shallow lake in Oakland County, MI, were available from the Michigan Department of Natural Resources (Waterford Fisheries Office, Waterford, MI) for late April through late October 2009, and we used these water temperatures for developing a water temperature regime for bluegills in Squaw Lake. Daily water temperatures were averaged by half-month period, and then each average water temperature was assigned to the midpoint of the half-month period (Figure 2). This same methodology was used in a walleye bioenergetics modeling study [44]. To complete the water temperature regime, water temperature from late December through early March was assumed to be $2{ }^{\circ} \mathrm{C}$ and water temperature in late March was assumed to be $3{ }^{\circ} \mathrm{C}[49,50]$. Further, water temperature was assumed to linearly increase from late March to late April and to linearly decrease from late October to late December. Diet composition data for bluegills were taken from Laarman and Schneider [51], who identified the major prey categories (percent of diet on a wet-weight basis enclosed within parentheses) as terrestrial insects (39\%), chironomids (20\%), cladocerans (19\%), other aquatic insects $(13 \%)$, aquatic plants $(8 \%)$, and fish (1\%). Energy densities of terrestrial insects, chironomids, cladocerans, other aquatic insects, aquatic plants, and fish were assigned values of $6019,3138,1674,4150,2978$, and $2300 \mathrm{~J} / \mathrm{g}$ wet weight, respectively, based on published data [47,52-56]. Bluegill energy density was assigned a value of $4186 \mathrm{~J} / \mathrm{g}$ wet weight [46].

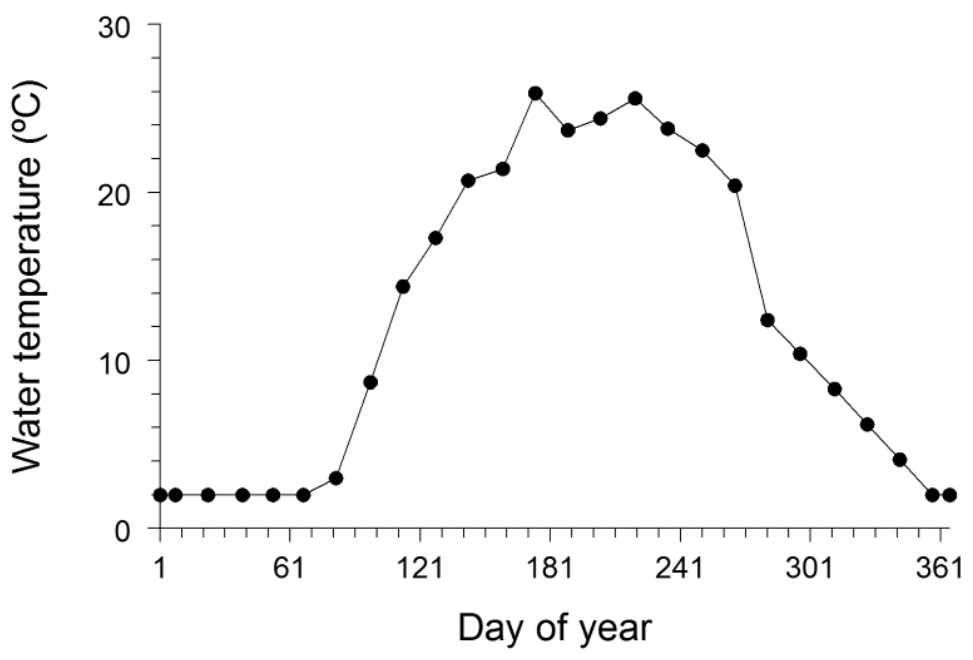

Figure 2. Water temperature regime used in the bioenergetics model application to growth data for bluegills in Squaw Lake (Oakland County, MI, USA). This water temperature regime was primarily based on daily water temperatures observed in Greens Lake (Oakland County, MI, USA) during 2009. Day 1 was 1 January, and day 365 was 31 December. See text for more details.

Cumulative GGE for each sex of bluegill was calculated by dividing the increase in bluegill weight by the cumulative amount of food consumption, as estimated by the bioenergetics modeling, needed to attain the observed growth. The ratio of cumulative GGE for males to cumulative GGE for females for 
each of the bluegill ages 2-8 was then calculated. If the growth dilution effect were to fully explain the difference in $\mathrm{Hg}$ concentrations between the sexes, then the ratio of GGE for males to GGE for females would equal the ratio of $\mathrm{Hg}$ concentration in females to $\mathrm{Hg}$ concentration in males.

\section{Results}

\subsection{Hg Concentrations}

Assignment of sex in the field based on coloration patterns was accurate for 53 of the 54 bluegills. Just one female bluegill was incorrectly identified as a male in the field. Aging structures were not taken from one of the males, and therefore an age estimate was not available for this male. The skin-off fillet homogenate for one of the females was lost, and so the skin-off fillet $\mathrm{Hg}$ concentration for this female was missing from the data set. Although the mean ages were similar between the sexes, male bluegills were larger than female bluegills (Table 1). Ages of males ranged between 3 and 8 years, and ages of females ranged between 4 and 8 years. Males averaged $179 \mathrm{~mm}$ in TL, whereas females averaged $167 \mathrm{~mm}$ in TL. Likewise, males averaged $105 \mathrm{~g}$ in weight, whereas females averaged $81 \mathrm{~g}$ in weight (Table 1).

Table 1. Mean (standard error of the mean enclosed within parentheses) for total length, weight, and age of adult bluegills, by sex, caught in Squaw Lake (Oakland County, MI, USA) during May 2013.

\begin{tabular}{ccccc}
\hline \multirow{2}{*}{ Attribute } & \multicolumn{3}{c}{ Females } & \multicolumn{2}{c}{ Males } \\
\cline { 2 - 5 } & $\mathbf{N}$ & Mean & N & Mean \\
\hline Total length $(\mathrm{mm})$ & 28 & $167(4)$ & 26 & $179(5)$ \\
Weight $(\mathrm{g})$ & 28 & $81(6)$ & 26 & $105(7)$ \\
Age (years) & 28 & $5.3(0.2)$ & 25 & $5.2(0.3)$ \\
\hline
\end{tabular}

$\mathrm{N}=$ number of observations.

Skin-off fillet $\mathrm{Hg}$ concentration was significantly higher in females than in males (ANCOVA: $F=4.62 ; \mathrm{df}=1,49 ; p=0.0366$ ) (Figure 3). Similarly, whole-fish $\mathrm{Hg}$ concentration was significantly higher in females than in males (ANCOVA: $F=4.86$; $\mathrm{df}=1,50 ; p=0.0321$ ). Age had a significantly positive effect on both skin-off fillet $\mathrm{Hg}$ concentration (ANCOVA: $F=20.30$; df=1,49; $p<0.0001$ ) and whole-fish $\mathrm{Hg}$ concentration (ANCOVA: $F=9.09$; $\mathrm{df}=1,50 ; p=0.0040$ ). Our use of ANCOVA was appropriate, because slopes of the regression lines of skin-off fillet $\mathrm{Hg}$ concentration as a function of age did not significantly vary between the sexes $(F=0.33 ; \mathrm{df}=1,48 ; p=0.5708)$, and similarly the slopes of the regression lines of whole-fish $\mathrm{Hg}$ concentration as a function of age did not significantly vary between the sexes $(F=0.12 ; \mathrm{df}=1,49 ; p=0.7325)$. 


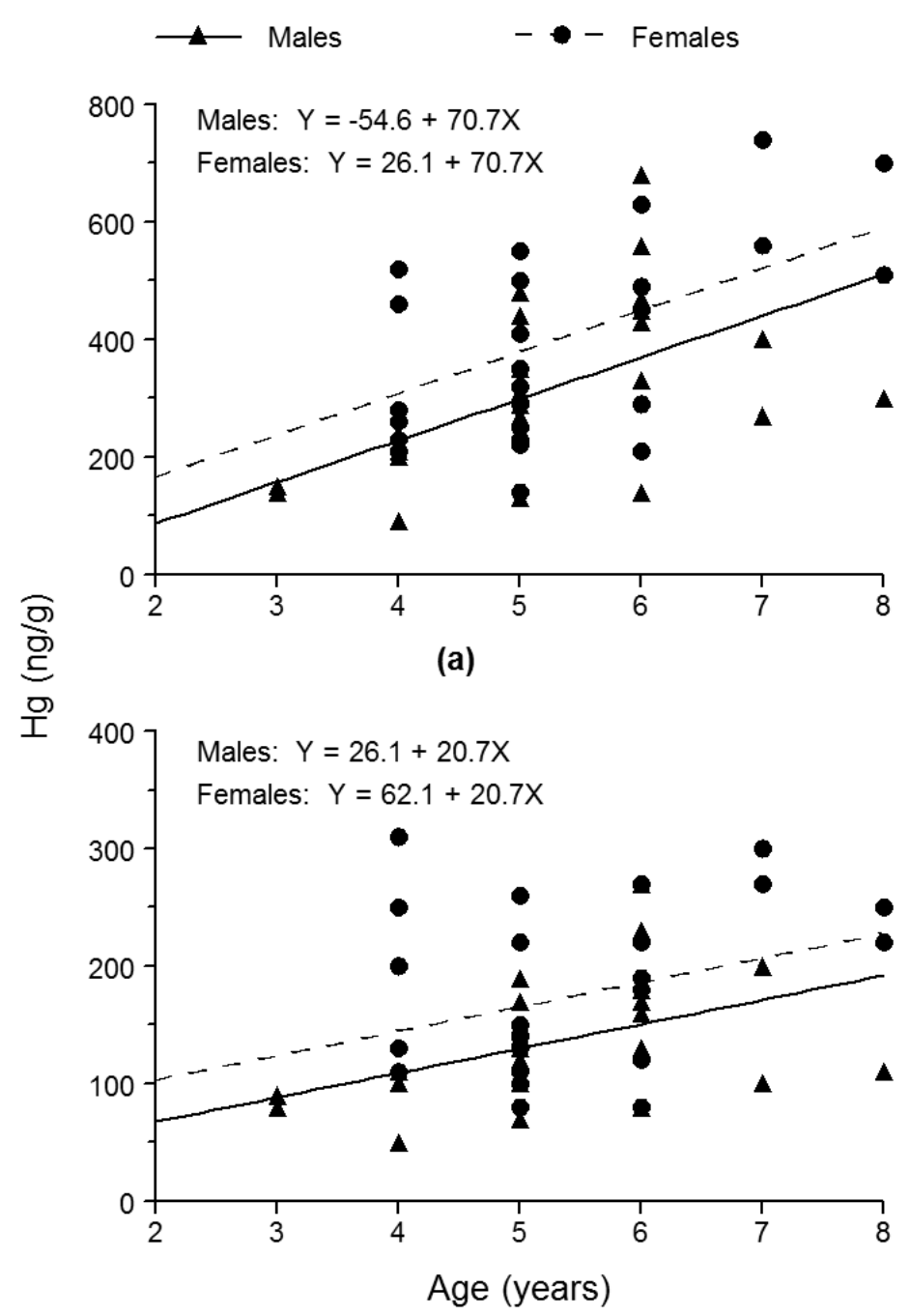

(b)

Figure 3. (a) Skin-off fillet $\mathrm{Hg}$ concentration as a function of age for adult bluegills caught in Squaw Lake (Oakland County, MI, USA) during May 2013. Fitted regression lines from the ANCOVA application to the $\mathrm{Hg}$ concentrations are also displayed. (b) Whole-fish $\mathrm{Hg}$ concentration as a function of age for adult bluegills caught in Squaw Lake (Oakland County, MI, USA) during May 2013. Fitted regression lines from the ANCOVA application to the $\mathrm{Hg}$ concentrations are also displayed.

Substitution of the grand mean for age into our fitted ANCOVA model yielded estimates of mean skin-off fillet $\mathrm{Hg}$ concentrations of $399 \mathrm{ng} / \mathrm{g}$ for females and $318 \mathrm{ng} / \mathrm{g}$ for males. Thus, on average, females were $25.4 \%$ greater in skin-off fillet $\mathrm{Hg}$ concentration compared with males. Substitution of the grand mean for age into our fitted ANCOVA yielded estimates of mean whole-fish $\mathrm{Hg}$ concentrations of $171 \mathrm{ng} / \mathrm{g}$ for females and $135 \mathrm{ng} / \mathrm{g}$ for males. Thus, on average, females were $26.6 \%$ greater in whole-fish $\mathrm{Hg}$ concentration compared with males.

Skin-off fillet $\mathrm{Hg}$ concentration was significantly greater than whole-fish $\mathrm{Hg}$ concentration $(t$ test: $t=14.44 ;$ df $=53 ; p<0.0001)$. Based on the results of this comparison, skin-off fillet $\mathrm{Hg}$ concentration averaged $363 \mathrm{ng} / \mathrm{g}$, whereas mean whole-fish $\mathrm{Hg}$ concentration was only $155 \mathrm{ng} / \mathrm{g}$. Thus, mean skin-off fillet $\mathrm{Hg}$ concentration was 2.3 times greater than mean whole-fish $\mathrm{Hg}$ concentration. 


\subsection{Bioenergetics Modeling}

Between ages 2 and 5, males grew substantially faster than females, and males remained larger than females through age 8 (Table 2). Cumulative GGE decreased from 0.188 to 0.126 for females between ages 2 and 5, but decreased only from 0.188 to 0.149 for males over this same range of ages. At ages 3 and 4 , males were nearly $20 \%$ more efficient at converting food into their own body mass than females (Figure 4). Applying a weighted average (weighting by the number of fish in our sample for each of the age groups) to the ratio of cumulative GGE for males to cumulative GGE for females over ages 3-8, males had a 14.4\% higher cumulative GGE over ages 3-8 compared with females. Thus, the growth dilution effect could account for females being $14.4 \%$ greater in whole-fish $\mathrm{Hg}$ concentration compared with males.

Table 2. Cumulative consumption and cumulative gross growth efficiency (GGE), by age and sex, for bluegills from Squaw Lake (Oakland County, MI, USA).

\begin{tabular}{ccccccc}
\hline \multirow{2}{*}{ Age (years) } & \multicolumn{3}{c}{ Females } & \multicolumn{3}{c}{ Males } \\
\cline { 2 - 6 } & $\begin{array}{c}\text { Weight at } \\
\text { age (g) }\end{array}$ & $\begin{array}{c}\text { Cumulative } \\
\text { consumption (g) }\end{array}$ & $\begin{array}{c}\text { Cumulative } \\
\text { GGE }\end{array}$ & $\begin{array}{c}\text { Weight at } \\
\text { age (g) }\end{array}$ & $\begin{array}{c}\text { Cumulative } \\
\text { consumption (g) }\end{array}$ & $\begin{array}{c}\text { Cumulative } \\
\text { GGE }\end{array}$ \\
\hline 2 & 15 & 80 & 0.188 & 15 & 80 & 0.188 \\
3 & 33 & 193 & 0.171 & 47 & 230 & 0.204 \\
4 & 51 & 351 & 0.145 & 79 & 455 & 0.174 \\
5 & 70 & 554 & 0.126 & 111 & 743 & 0.149 \\
6 & 92 & 803 & 0.115 & 133 & 1063 & 0.125 \\
7 & 114 & 1095 & 0.104 & 155 & 1420 & 0.109 \\
8 & 136 & 1427 & 0.095 & 177 & 1812 & 0.098 \\
\hline
\end{tabular}

Estimates of consumption based on application of the Wisconsin bioenergetics model.

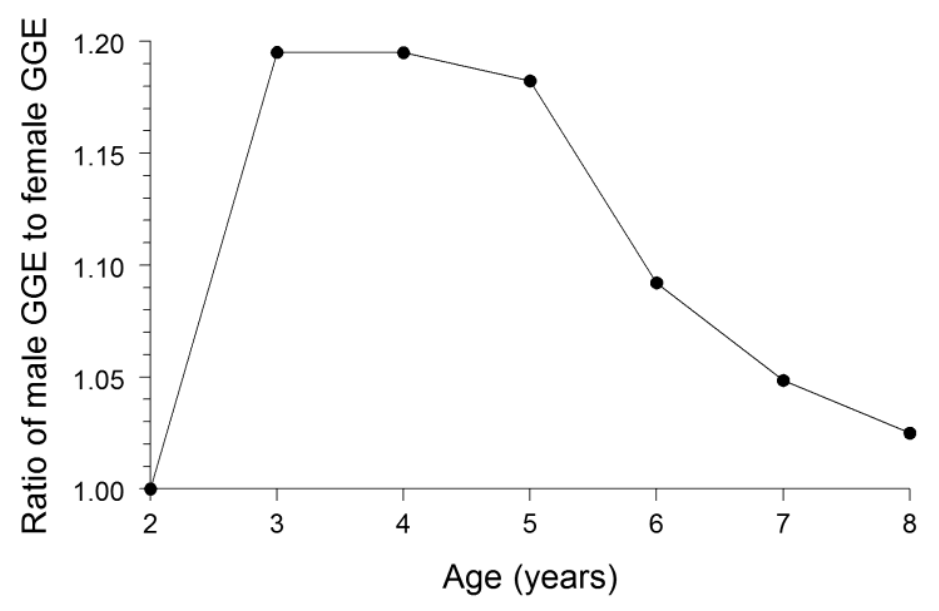

Figure 4. Ratio of GGE for males to GGE for females as a function of bluegill age. Gross growth efficiency (GGE) was estimated by applying the bluegill bioenergetics model by Kitchell et al. [45], with suggested modification by Breck [47], to growth data for male and female bluegills caught in Squaw Lake (Oakland County, MI, USA) during May 2013. Refer to the text for more details on the bioenergetics model application. 


\section{Discussion}

We conclude that the most plausible explanation for the female bluegills having whole-fish $\mathrm{Hg}$ concentrations $27 \%$ greater than that of male bluegills was: (1) males grew substantially faster than females, and (2) males eliminated $\mathrm{Hg}$ from their bodies at a faster rate than females. The faster growth in males resulted in a greater dilution of the accumulated $\mathrm{Hg}$ in males. Our bioenergetics modeling results indicated that the growth dilution effect could account for females being $14 \%$ higher in $\mathrm{Hg}$ concentration than males. Thus, the growth dilution effect was responsible for most of the observed difference in $\mathrm{Hg}$ concentrations between the sexes. Nonetheless, a substantially faster rate of $\mathrm{Hg}$ elimination by males compared with females was likely another important factor driving the difference in $\mathrm{Hg}$ concentrations between the sexes. Given that male bluegills probably ingested food (and $\mathrm{Hg}$ ) at a higher rate than female bluegills owing to a higher rate of energy expenditure by males [30], the growth dilution effect and the higher Hg-elimination rate in males compared with females more than compensated for this presumably higher rate of $\mathrm{Hg}$ ingestion by males. Thus, female bluegills were higher in $\mathrm{Hg}$ concentration than males.

Our results indicated that the bluegill can be added to the list of fish species in which females exhibit higher whole-fish $\mathrm{Hg}$ concentrations than males. Female burbot (Lota lota) were found to be $22 \%$ greater in $\mathrm{Hg}$ concentration than male burbot [31]. Similarly, we documented that female bluegills were $27 \%$ higher in $\mathrm{Hg}$ concentration than male bluegills. However, the growth dilution effect made no contribution whatsoever to the observed difference in $\mathrm{Hg}$ concentrations between the sexes of burbot [31], whereas we concluded that the growth dilution effect was the primary driver of the observed difference in $\mathrm{Hg}$ concentrations between the sexes of bluegill. Thus, these results suggested that the relative difference in $\mathrm{Hg}$-elimination rates between the sexes of burbot exceeded the relative difference in $\mathrm{Hg}$-elimination rates between the sexes of bluegill. Androgens such as testosterone and 11-ketotestosterone may enhance $\mathrm{Hg}$-elimination rate in male teleost fishes [31].

We found that female bluegills were significantly higher in $\mathrm{Hg}$ concentration than male bluegills. Similarly, Nicoletto and Hendricks [33] concluded that females were significantly greater in $\mathrm{Hg}$ concentration than males in four species of sunfishes, including bluegill. However, we estimated the relative difference in $\mathrm{Hg}$ concentrations between the sexes to be $26.6 \%$, whereas Nicoletto and Hendricks [33] reported the relative difference between the sexes to be as high as $45 \%$. A plausible explanation for this difference between our results and the results from the Nicoletto and Hendricks [33] study was that our results were based on whole-fish $\mathrm{Hg}$ determinations, whereas the Nicoletto and Hendricks [33] study was based on determinations of $\mathrm{Hg}$ concentration in a small (about $0.5 \mathrm{~g}$ ) plug of white muscle. Perhaps, use of a small plug of white muscle tissue inflated the relative difference in $\mathrm{Hg}$ concentrations between the sexes. Alternatively, other factors may have been responsible for this difference between our results and those of Nicoletto and Hendricks [33]. Nonetheless, our findings also indicated that skin-off fillet $\mathrm{Hg}$ concentrations accurately reflected the relative difference in whole-fish $\mathrm{Hg}$ concentrations between the sexes of bluegill. Females were $25.4 \%$ and $26.6 \%$ higher in skin-off fillet and whole-fish $\mathrm{Hg}$ concentrations, respectively, than males.

Whole-fish $\mathrm{Hg}$ determinations are useful in ecological studies in which $\mathrm{Hg}$ is used as a tracer of food consumption by fish [57,58], whereas fillet $\mathrm{Hg}$ determinations are used in developing fish consumption advisories [28,29]. Becker and Bigham [35] concluded that for most fish species, fillet $\mathrm{Hg}$ concentrations 
are just $10 \%$ greater, on average, than whole-fish $\mathrm{Hg}$ concentrations. Thus, fillet $\mathrm{Hg}$ concentration has been used as a surrogate for whole-fish $\mathrm{Hg}$ concentration in food tracer studies [57,58]. However, Becker and Bigham [35] noted that in the case of bluegill, fillet $\mathrm{Hg}$ concentration was substantially greater than whole-fish $\mathrm{Hg}$ concentration. Similarly, we found that skin-off fillet $\mathrm{Hg}$ concentration exceeded whole-fish $\mathrm{Hg}$ concentration by a factor of 2.3 , on average, in bluegills.

Our findings should prove useful in revising consumption advisories for bluegills caught in small inland lakes in southeastern Michigan. The Michigan Department of Health and Human Services (MDHHS), U.S. Environmental Protection Agency (EPA), Ontario Ministry of the Environment (OMOE), and U.S. Food and Drug Administration (FDA) have set thresholds of 70, 300, 610 (for the general public), and $1000 \mathrm{ng} / \mathrm{g}$, respectively, for $\mathrm{Hg}$ concentrations in fish eaten by people, and these agencies advise either restricted consumption or no consumption when these thresholds are exceeded $[29,59,60]$. Mean skin-off fillet $\mathrm{Hg}$ concentration of Squaw Lake bluegill was estimated to be $363 \mathrm{ng} / \mathrm{g}$, which exceeds the EPA guideline. Further, all 53 skin-off fillet $\mathrm{Hg}$ concentrations determined in our study exceeded the MDHHS threshold, 28 exceeded the EPA guideline, and four exceeded the OMOE guideline. Based on the observed Hg concentrations, the MDHHS would advise restricting consumption of Squaw Lake bluegills to no more than two meals per month, guidance that is more restrictive than the agency's recommendation of eight meals per month for bluegills from untested waters [60]. Clearly, bluegills in at least some of the small inland lakes in southeastern Michigan have elevated $\mathrm{Hg}$ concentrations relative to the state average. As such, additional monitoring of fish tissue $\mathrm{Hg}$ concentrations in these small lakes would be very useful in revising consumption advisories.

Our findings will also be useful in refining the mercury mass balance models used to estimate food consumption by fish. Use of mercury mass balance models to estimate food consumption by fish has dramatically increased since $2000[57,58,61,62]$. The mercury elimination submodel used in these mass balance models does not allow for the Hg-elimination rate to vary by fish species or sex [63]. However, recent research has shown that $\mathrm{Hg}$-elimination rates may vary substantially between fish species, as well as between the sexes of a particular species of fish [31,32]. Concentrations of certain androgens appear to play an important role in regulating $\mathrm{Hg}$-elimination rate. Our $\mathrm{Hg}$ determinations can be used to further refine the mercury mass balance model for bluegills.

Conclusions from our bioenergetics modeling were robust to uncertainties in the model inputs. We have defined the growth dilution effect as the relative difference in GGEs between the sexes solely due to a difference in growth rates between the sexes. The degree of bias in GGE estimates arising from inaccuracies in the values used for model inputs should be similar for both sexes. Thus, the ratio of GGE in males to GGE in females should be relatively unaffected by these biases. In addition, results from sensitivity analyses for fish bioenergetics models in previous studies have indicated that model estimates of food consumption are relatively insensitive to perturbations in the values of most of the model parameters $[64,65]$. Further, the remaining model parameters, for which perturbations in their values have a relatively large effect on food consumption estimates, are often associated with a high degree of confidence in their estimated values. Finally, laboratory evaluations of fish bioenergetics model performance have revealed that bioenergetics model estimates of cumulative food consumption by fish over an extended period of time (3-14 months) are typically within $10 \%$ of the observed cumulative food consumption $[66,67]$. 
We may expect the relative differences in PCB concentrations between the sexes of bluegill from Squaw Lake to be somewhat lower than the relative differences in PCB concentrations between the sexes of other fish populations previously documented. Based on data for six fish species (other than bluegill), mature males were $15 \%-45 \%$ higher in PCB concentrations than mature females, and these higher PCB concentrations in the males were primarily attributable to a greater rate of energy expenditure in males, stemming from higher activity and a greater SMR [30]. Thus, not only do males apparently exceed females in swimming activity, but males apparently expend energy at a higher rate than females when both sexes are at rest. Averaging across these six fish species, males were 25\%-30\% greater in PCB concentration compared with females. For two of these six fish species, growth did not vary between the sexes. For the other four fish species, females grew faster than males. However, the growth dilution effect was found to make a substantial contribution to the observed difference in PCB concentrations between the sexes in only one of these four species [34,44]. Given the results of our study indicating that the growth dilution effect would lead to female bluegills being 14\% higher in PCB concentration than male bluegills, we may expect that PCB concentration in male bluegills would exceed PCB concentration in female bluegills by only $10 \%-15 \%$. Release at eggs by females at spawning was considered to be a potential factor contributing to the higher PCB concentrations observed in males, but was concluded to be an unimportant contributor to the relative difference in PCB concentrations between the sexes in most cases [30,34]. One of the main reasons for this conclusion was that two of the six above-mentioned fish species were semelparous. That is, for these two species, the fish spawned only once during their lifetime and died soon thereafter. Moreover, the fish were caught prior to spawning. Thus, release of eggs at spawning could not, in any way, account for the higher PCB concentrations in the males because the fish had never spawned prior to capture. In addition, determinations of PCB concentrations in both the ovaries and the somatic tissue of ripe females have shown that in several species of fish, the PCB concentration in the somatic tissue exceeds the PCB concentration in the ovaries [30,34]. Thus, when the female releases her eggs, her PCB concentration actually increases. An increase in the PCB concentration of the females immediately after spawning due to release of eggs could not, in any way, explain the higher PCB concentrations in males. Note that even though the PCB body burden of females decreases immediately after spawning due to release of eggs, PCB concentration of females will actually increase immediately after spawning if the PCB concentration of the eggs is lower than the PCB concentration of the somatic tissue [34].

\section{Conclusions}

Squaw Lake, a small and shallow lake in southeastern Michigan (USA), was the site of our study. Adult female bluegills from Squaw Lake averaged $171 \mathrm{ng} / \mathrm{g}$ in whole-fish $\mathrm{Hg}$ concentration, whereas adult male bluegills from Squaw Lake averaged $135 \mathrm{ng} / \mathrm{g}$ in whole-fish $\mathrm{Hg}$ concentration. Thus, females were $26.6 \%$ greater in whole-fish $\mathrm{Hg}$ concentration than males. We conclude that this difference between the sexes was most likely attributable to: (1) males growing at a substantially faster rate than females, and (2) males eliminating $\mathrm{Hg}$ from their bodies at a substantially faster rate than females. Bioenergetics modeling results indicated that the faster growth by males could account for females being $14.4 \%$ higher in $\mathrm{Hg}$ concentration compared with males. Thus, this growth dilution 
effect accounted for most of the difference in $\mathrm{Hg}$ concentrations between the sexes. Previous research results have indicated that $\mathrm{Hg}$-elimination rate for males is considerably faster than that for females in teleost fishes, and this presumed difference in Hg-elimination rates between the sexes could explain the remaining portion of the difference in whole-fish $\mathrm{Hg}$ concentrations between the sexes of the bluegills.

Determinations of skin-off fillet $\mathrm{Hg}$ concentrations in the bluegills showed that the relative difference in skin-off fillet $\mathrm{Hg}$ concentrations between the sexes was similar to the relative difference in whole-fish $\mathrm{Hg}$ concentrations between the sexes. Skin-off fillet and whole-fish $\mathrm{Hg}$ concentrations were $25.4 \%$ higher and $26.6 \%$ higher, respectively, in females than in males, on average. Nevertheless, mean skin-off fillet $\mathrm{Hg}$ concentration $(363 \mathrm{ng} / \mathrm{g}$ ) was 2.3 times greater than mean whole-fish $\mathrm{Hg}$ concentration $(155 \mathrm{ng} / \mathrm{g})$.

Our findings should be useful for revising consumption advisories for bluegills caught in small inland lakes in southeastern Michigan, as well as for refining mercury mass balance models used to estimate food consumption by fish. Mean skin-off fillet $\mathrm{Hg}$ concentration for Squaw Lake bluegills was $363 \mathrm{ng} / \mathrm{g}$, which was considerably higher than the average concentration for bluegills in the Michigan Department of Health and Human Services (MDHHS) database. At this elevated level, the MDHHS would advise restricting consumption of Squaw Lake bluegills to no more than two meals per month. In contrast, the agency's recommendation would be eight meals per month for untested waters in Michigan. Additional monitoring of fish tissue $\mathrm{Hg}$ concentrations in these small lakes would also be very useful in revising fish consumption advisories. At present, the mercury elimination submodel used in mercury mass balance models does not allow for the Hg-elimination rate to vary by fish species or sex. Yet, results from recent research have indicated that Hg-elimination rates can differ between species and sexes. Our results can be used to further refine the mercury mass balance model for bluegills, thereby leading to more accurate estimates of food consumption by bluegills.

\section{Acknowledgments}

We thank Dennis Tar for assistance with the fieldwork, Danielle Forsythe for preparing the map of Squaw Lake, Paige Wigren and Kelley Smith for transporting the frozen bluegills from the Waterford Fisheries Station to the Bureau of Laboratories, and Michelle Selzer for reviewing a draft manuscript and making suggestions for manuscript improvement. Use of trade, product, or firm names does not imply endorsement by the U.S. Government. This article is Contribution 1985 of the U.S. Geological Survey Great Lakes Science Center.

\section{Author Contributions}

Charles Madenjian developed the initial idea for this research. James Francis, Jeffrey Braunscheidel, and Charles Madenjian undertook the fieldwork. Joseph Bohr, Matthew Geiger, and Mark Knottnerus determined the $\mathrm{Hg}$ concentrations in the bluegills. Charles Madenjian performed the statistical analyses and the bioenergetics modeling. Charles Madenjian, James Francis, Jeffrey Braunscheidel, Joseph Bohr, Matthew Geiger, and Mark Knottnerus wrote the manuscript. 


\section{Conflicts of Interest}

The authors declare no conflict of interest.

\section{References}

1. Drake, M.T.; Claussen, J.E.; Philipp, D.P.; Pereira, D.L. A comparison of bluegill reproductive strategies and growth among lakes with different fishing intensities. N. Am. J. Fish. Manag. 1997, 17, 496-507.

2. Edison, T.W.; Wahl, D.H.; Diana, M.J.; Philipp, D.P.; Austen, D.J. Angler opinion of potential bluegill regulations on Illinois lakes: Effects of angler demographics and bluegill population size structure. N. Am. J. Fish. Manag. 2006, 26, 800-811.

3. Spotte, S. Bluegills: Biology and Behavior; American Fisheries Society: Bethesda, MD, USA, 2007.

4. Wilson, A.D.M.; Binder, T.R.; McGrath, K.P.; Cooke, S.J.; Godin, J.-G.J. Capture technique and fish personality: Angling targets timid bluegill sunfish, Lepomis macrochirus. Can. J. Fish. Aquat. Sci. 2011, 68, 749-757.

5. Ikem, A.; Egilla, J. Trace element content of fish feed and bluegill sunfish (Lepomis macrochirus) from aquaculture and wild source in Missouri. Food Chem. 2008, 110, 301-309.

6. Tsunoda, H.; Mitsuo, Y.; Ohira, M.; Senga, Y. Stomach contents of introduced bluegill in Lake Shojiko, Yamanashi Prefecture. J. Environ. Inform. Sci. 2011, 39, 1-8.

7. Beard, T.D., Jr.; Drake, M.T.; Breck, J.E.; Nate, N.A. Effects of simulated angling regulations on stunting in bluegill populations. N. Am. J. Fish. Manag. 1997, 17, 525-532.

8. Jennings, M.J.; Claussen, J.E.; Philipp, D.P. Effect of population size structure on reproductive investment of male bluegill. N. Am. J. Fish. Manag. 1997, 17, 516-524.

9. Schneider, J.C.; Lockwood, R.N. Experimental Management of Stunted Bluegill Lakes; Fisheries Research Report 2040; Michigan Department of Natural Resources: Ann Arbor, MI, USA, 1997.

10. Beard, T.D., Jr.; Essington, T.E. Effects of angling and life history processes on bluegill size structure: Insights from an individual-based model. Trans. Am. Fish. Soc. 2000, 129, 561-568.

11. Porath, M.T.; Hurley, K.L. Effects of waterbody type and management actions on bluegill growth rates. N. Am. J. Fish. Manag. 2005, 25, 1041-1050.

12. Dominey, W.J. Female mimicry in male bluegill sunfish-A genetic polymorphism? Nature 1980, 284, 546-548.

13. Gross, M.R.; Charnov, E.L. Alternative male life histories in bluegill sunfish. Proc. Natl. Acad. Sci. U. S. A. 1980, 77, 6937-6940.

14. Gross, M.R. Sneakers, satellites, and parentals: Polymorphic mating strategies in North American sunfishes. Z. Tierpsychol. 1982, 60, 1-26.

15. Claussen, J.E. Annual Variation in Reproductive Activity of a Bluegill Population: Effect of Clutch Size and Temperature. Master's Thesis, University of Toronto, Toronto, ON, Canada, 1991.

16. Aday, D.D.; Wahl, D.H.; Philipp, D.P. Assessing population-specific and environmental influences on bluegill life histories: A common garden approach. Ecology 2003, 84, 3370-3375. 
17. Wiener, J.G.; Krabbenhoft, D.P.; Heinz, G.H.; Scheuhammer, A.M. Ecotoxicology of mercury. In Handbook of Ecotoxicology, 2nd ed.; Hoffman, D.J., Rattner, B.A., Burton, G.A., Jr., Cairns, J., Jr., Eds.; CRC Press: Boca Raton, FL, USA, 2003; pp. 407-461.

18. WHO (World Health Organization). Ten Chemicals of Major Public Health Concern, 2010. Available online: http://www.who.int//ipcs/assessment/public_health/chemicals_phc/en/ (accessed on 1 October 2015).

19. Scheuhammer, A.M.; Meyer, M.W.; Sandheinrich, M.B.; Murray, M.W. Effects of environmental methylmercury on the health of wild birds, mammals, and fish. Ambio J. Human Environ. 2007, $36,12-18$.

20. Sandheinrich, M.B.; Bhavsar, S.P.; Bodaly, R.A.; Drevnick, P.E.; Paul, E.A. Ecological risk of methylmercury to piscivorous fish of the Great Lakes region. Ecotoxicology 2011, 20, 1577-1587.

21. Wiener, J.G.; Evers, D.C.; Gay, D.A.; Morrison, H.A.; Williams, K.A. Mercury contamination in the Laurentian Great Lakes region: Introduction and overview. Environ. Pollut. 2012, 161, 243-251.

22. Clarkson, T.W.; Magos, L.; Myers, G.J. The toxicology of mercury-Current exposures and clinical manifestations. N. Engl. J. Med. 2003, 349, 1731-1737.

23. Somers, E.C.; Ganser, M.A.; Warren, J.S.; Basu, N.; Wang, L.; Zick, S.M.; Park, S.K. Mercury exposure and antinuclear antibodies among females of reproductive age in the United States: NHANES. Environ. Health Perspect. 2015, 123, 792-798.

24. Wren, C.D. A review of metal accumulation and toxicity in wild mammals. I. Mercury. Environ. Res. 1986, 40, 210-244.

25. Ginsberg, G.L.; Toal, B.E. Development of a single-meal fish consumption advisory for methyl mercury. Risk Analys. 2000, 20, 41-47.

26. Burger, J.; Gochfeld, M.; Powers, C.W.; Waishwell, L.; Warren, C.; Goldstein, B.D. Science, policy, stakeholders, and fish consumption advisories: Developing a fish fact sheet for the Savannah River. Environ. Manag. 2001, 27, 501-514.

27. Pastorok, R.A.; Bartell, S.M.; Ferson, S.; Ginzburg, L.R. Ecological Modeling in Risk Assessment: Chemical Effects on Populations, Ecosystems, and Landscapes; Lewis: Boca Raton, FL, USA, 2002.

28. McClain, W.C.; Chumchal, M.M.; Drenner, R.W.; Newland, L.W. Mercury concentrations in fish from Lake Meredith, Texas: Implications for the issuance of fish consumption advisories. Environ. Monit. Assess. 2006, 123, 249-258.

29. Cai, Y.; Rooker, J.R.; Gill, G.A.; Turner, J.P. Bioaccumulation of mercury in pelagic fishes from the northern Gulf of Mexico. Can. J. Fish. Aquat. Sci. 2007, 64, 458-469.

30. Madenjian, C.P.; Yule, D.L.; Chernyak, S.M.; Begnoche, L.J.; Berglund, E.K.; Isaac, E.J. Males exceed females in PCB concentrations of cisco (Coregonus artedi) from Lake Superior. Sci. Total Environ. 2014, 493, 377-383.

31. Madenjian, C.P.; Stapanian, M.A.; Cott, P.A.; Krabbenhoft, D.P.; Edwards, W.H.; Ogilvie, L.M.; Mychek-Londer, J.G.; DeWild, J.F. Females exceed males in mercury concentrations of burbot Lota lota. Arch. Environ. Contam. Toxicol. 2015, 68, 678-688. 
32. Madenjian, C.P.; Blanchfield, P.J.; Hrenchuk, L.E.; Van Walleghem, J.L.A. Mercury elimination rates for adult northern pike Esox. lucius: Evidence for a sex effect. Bull. Environ. Contam. Toxicol. 2014, 93, 144-148.

33. Nicoletto, P.F.; Hendricks, A.C. Sexual differences in accumulation of mercury in four species of centrarchid fishes. Can. J. Zool. 1988, 66, 944-949.

34. Madenjian, C.P. Sex effect on polychlorinated biphenyl concentrations in fish: A synthesis. Fish. Fish. 2011, 12, 451-460.

35. Becker, D.S.; Bigham, G.N. Distribution of mercury in the aquatic food web of Onondaga Lake, New York. Water Air Soil Pollut. 1995, 80, 563-571.

36. Sveinsdottir, A.Y.; Mason, R.P. Factors controlling mercury and methylmercury concentrations in largemouth bass (Micropterus salmoides) and other fish from Maryland reservoirs. Arch. Environ. Contam. Toxicol. 2005, 49, 528-545.

37. Sackett, D.K.; Aday, D.D.; Rice, J.A.; Cope, W.G. A statewide assessment of mercury dynamics in North Carolina water bodies and fish. Trans. Am. Fish. Soc. 2009, 138, 1328-1341.

38. Sackett, D.K.; Aday, D.D.; Rice, J.A.; Cope, W.G.; Buchwalter, D. Does proximity to coal-fired power plants influence fish tissue mercury? Ecotoxicology 2010, 19, 1601-1611.

39. Schneider, J.C.; Merna, J.W. Fishing gear. In Manual of Fisheries Survey Methods II: With Periodic Updates; Schneider, J.C., Ed.; Fisheries Special Report 25; Michigan Department of Natural Resources: Ann Arbor, MI, USA, 2000; Chapter 3.

40. Kodric-Brown, A. Sexual dichromatism and temporary color changes in the reproduction of fishes. Amer. Zool. 1998, 38, 70-81.

41. Schneider, J.C.; Laarman, P.W.; Gowing, H. Age and growth methods and state averages. In Manual of Fisheries Survey Methods II: With Periodic Updates; Schneider, J.C., Ed.; Fisheries Special Report 25; Michigan Department of Natural Resources: Ann Arbor, MI, USA, 2000; Chapter 9.

42. USEPA (United States Environmental Protection Agency). Method 7473: Mercury in Solids and Solutions by Thermal Decomposition, Amalgamation, and Atomic Absorption Spectrophotometry, Revision 0, February 2007; Office of Water: Washington, DC, USA, 2007.

43. Rudstam, L.G.; Binkowski, F.P.; Miller, M.A. A bioenergetics model for analysis of food consumption patterns of bloater in Lake Michigan. Trans. Am. Fish. Soc. 1994, 123, 344-357.

44. Madenjian, C.P.; Hanchin, P.A.; Chernyak, S.M.; Begnoche, L.J. Sexual difference in PCB concentrations of walleyes (Sander vitreus) from a pristine lake. Sci. Total Environ. 2009, 407, 4526-4532.

45. Kitchell, J.F.; Koonce, J.F.; O’Neill, R.V.; Shugart, H.H., Jr.; Magnuson, J.J.; Booth, R.S. Model of fish biomass dynamics. Trans. Am. Fish. Soc. 1974, 113, 786-798.

46. Hewett, S.W.; Johnson, B.L. A Generalized Bioenergetics Model. of Fish. Growth for Microcomputers; WIS-SG-87-245; University of Wisconsin Sea Grant Institute: Madison, WI, USA, 1987.

47. Breck, J.E. Hurry up and wait: Growth of young bluegills in ponds and in simulations with an individual-based model. Trans. Am. Fish. Soc. 1993, 122, 467-480.

48. Breck, J.E. Mechanisms of Recruitment Failure in Bluegill Ponds; Fisheries Research Report 2024; Michigan Department of Natural Resources: Ann Arbor, MI, USA, 1996. 
49. Greenbank, J. Limnological conditions in ice-covered lakes, especially as related to winter-kill of fish. Ecol. Monogr. 1945, 15, 343-392.

50. Madenjian, C.P.; Rutherford, E.S.; Blouin, M.A.; Sederberg, B.J.; Elliott, J.R. Spawning habitat unsuitability: An impediment to cisco rehabilitation in Lake Michigan? N. Am. J. Fish. Manag. 2011, 31, 905-913.

51. Laarman, P.W.; Schneider, J.C. The Food and Feeding Habits of the Bluegill and Yellow Perch in Lakes with Good and Poor Fishing; Research and Development Report 279; Michigan Department of Natural Resources: Ann Arbor, MI, USA, 1972.

52. Cummins, K.W.; Wuycheck, J.C. Caloric equivalents for investigations in ecological energetics. Int. Ver. Theor. Angew. Limnol. Verh. 1971, 18, 1-158.

53. Studier, E.H.; Sevick, S.H. Live mass, water content, nitrogen and mineral levels in some insects from south-central lower Michigan. Comp. Biochem. Physiol. 1992, 103A, 579-595.

54. Lantry, B.F.; Stewart, D.J. Ecological energetics of rainbow smelt in the Laurentian Great Lakes: An interlake comparison. Trans. Am. Fish. Soc. 1993, 122, 951-976.

55. Ciancio, J.; Pascual, M. Energy density of freshwater Patagonian organisms. Ecol. Austral. 2006, 16, 91-94.

56. Rumpold, B.A.; Schlüter, O. Insect-based protein sources and their potential for human consumption: Nutritional composition and processing. Anim. Front. 2015, 5, 20-24.

57. Trudel, M.; Tremblay, A.; Schetagne, R.; Rasmussen, J.B. Estimating food consumption rates of fish using a mercury mass balance model. Can. J. Fish. Aquat. Sci. 2000, 57, 414-428.

58. Trudel, M.; Rasmussen, J.B. Predicting mercury concentration in fish using mass balance models. Ecol. Appl. 2001, 11, 517-529.

59. OMOE (Ontario Ministry of the Environment). Guide to Eating Ontario Sport Fish. 2013-2014; Queen's Printer for Ontario: Toronto, ON, Canada, 2013.

60. MDCH (Michigan Department of Community Health). Michigan Fish. Consumption Advisory Program. Guidance Document; State of Michigan: Lansing, MI, USA, 2014. Available online: http://www.michigan.gov/documents/mdch/MDCH_MFCAP_Guidance_Document_417043_7.pdf (accessed on 30 August 2015).

61. Rennie, M.D.; Collins, N.C.; Shuter, B.J.; Rajotte, J.W.; Couture, P. A comparison of methods for estimating activity costs of wild fish populations: More active fish observed to grow slower. Can. J. Fish. Aquat. Sci. 2005, 62, 767-780.

62. Ferriss, B.E.; Essington, T.E. Can fish consumption rate estimates be improved by linking bioenergetics and mercury mass balance models? Application to tunas. Ecol. Model. 2014, 272, 232-241.

63. Trudel, M.; Rasmussen, J.B. Modeling the elimination of mercury by fish. Environ. Sci. Technol. 1997, 31, 1716-1722.

64. Stewart, D.J.; Weininger, D.; Rottiers, D.V.; Edsall, T.A. An energetics model for lake trout, Salvelinus namaycush: Application to the Lake Michigan population. Can. J. Fish. Aquat. Sci. 1983, 40, 681-698.

65. Bartell, S.M.; Breck, J.E.; Gardner, R.H.; Brenkert, A.L. Individual parameter perturbation and error analysis of fish bioenergetics models. Can. J. Fish. Aquat. Sci. 1986, 43, 160-168. 
66. Madenjian, C.P.; Pothoven, S.A.; Kao, Y.-C. Reevaluation of lake trout and lake whitefish bioenergetics models. J. Great Lakes Res. 2013, 39, 358-364.

67. Madenjian, C.P.; Wang, C. Reevaluation of a walleye (Sander vitreus) bioenergetics model. Fish. Physiol. Biochem. 2013, 39, 749-754.

(C) 2015 by the authors; licensee MDPI, Basel, Switzerland. This article is an open access article distributed under the terms and conditions of the Creative Commons Attribution license (http://creativecommons.org/licenses/by/4.0/). 